\title{
Nanoencapsulation- A Novel Strategy for Enhancing the Bioactivity of Essential Oils: A Review
}

Neha Sharma, Proloy Sankar Dev Roy, Aasiya Majeed, Khalid H. Salaria,

Rashmi Chalotra, Shubham Kailas Padekar, Sanjay Guleria

10.18805/IJARe.A-5806

\begin{abstract}
An upsurge in the global demand for safe and healthy food with minimal synthetic preservatives has raised the need for natural antimicrobial agents. Plant based products, especially essential oils (EOs) exhibit strong antimicrobial activities that could play a significant role as a novel source of food preservatives. However, hydrophobicity, high volatility, susceptibility to oxidation, low stability and solubility limit the uses of essential oils. Therefore, nanoencapsulation could be promising technique to address these limitations as it prevents the exposure and degradation of essential oils, by creating a physical barrier that protects the bioactive constituents. Furthermore, it also facilitates their controlled release, resulting into enhanced bioavailability as well as efficacy in the food system. Present review highlights the various encapsulating methods and provides insight about some encapsulated essential oils and their bioactive properties.
\end{abstract}

Key words: Antimicrobial, Essential oils (EOs), Nano-encapsulation, Preservatives.

Essential oils (EOs) are hydrophobic liquids containing various volatile compounds. In the $16^{\text {th }}$ century, the word 'essential oil' was defined as 'Quinta Essential' by Paracelsus von Hoenheim (Pichersky et al., 2006). EOs are produced in large quantities in oil sacs/oil glands of medicinal and aromatic plants and can be extracted from leaves, bark, seeds and flowers (Tongnuanchan and Benjakul, 2014; Mahato et al., 2019). They are a complex mix of over 300 different compounds which are mostly organic and volatile in nature (Vainstein et al., 2001; Pophof et al., 2005; Sell, 2006). Since medieval ages essential oils had been used in various cultures, due to their medicinal properties. Their various promising properties, like being stimulants, anti-depressants and anti-bacterial have helped them in gaining popularity in recent years. They have found applications in the field of therapeutics, being natural, safe and cost effective (Herman et al., 2019). Similarly their hydrophobic nature enable them to infuse into lipids of the cell membranes of microbes, resulting in disruption of the cell structure (Sikkema et al. 1994). Also different phenolic compounds present in them contribute to their anti-bacterial activity (Lambert et al., 2001; Dorman et al., 2000). In addition, EOs being lipophilic in nature, disrupt microbial cell homeostasis by making cells more permeable and less organized (Chaudhari et al., 2020).

In spite of their several advantages, the use of EOs is limited due to various intrinsic factors like high volatility, photo-sensitivity, hydrophobicity and low stability (Kumar et al., 2020). Therefore, in order to overcome these limitations associated with the use of essential oils there is a need for development of innovative technologies. Nanotechnology based techniques like nano-encapsulation has been developed as one such technology that has significant potential in addressing this problem. It involves the use of delivery vessels, also referred to as nano carriers to encapsulate
Natural Product-cum-Nano Lab, Division of Biochemistry, Faculty of Basic Sciences, Sher-e- Kashmir University of Agricultural Sciences and Technology of Jammu, Main Campus Chatha, Jammu-180 009, Jammu and Kashmir, India.

Corresponding Author: Sanjay Guleria, Natural Product-cum-Nano Lab, Division of Biochemistry, Faculty of Basic Sciences, Sher-eKashmir University of Agricultural Sciences and Technology of Jammu, Main Campus Chatha, Jammu-180 009, Jammu and Kashmir, India. Email: guleria71@gmail.com

How to cite this article: Sharma, N., Roy, P.S.D., Majeed, A., Salaria, K.H., Chalotra, R., Padekar, S.K. and Guleria, S. (2022). Nanoencapsulation- A Novel Strategy for Enhancing the Bioactivity of Essential Oils: A Review. Indian Journal of Agricultural Research. DOI: $10.18805 /$ IJARe.A-5806.

Submitted: 26-04-2021 Accepted: 23-12-2021 Online: 08-02-2022

bioactive molecules. This protect these molecules from various environmental factors such as oxygen, $\mathrm{pH}$, light etc. It also offers different advantages to EOs such as protection from degradation, enhanced bioactivity targeted delivery and controlled release (Singh et al., 2020; Bastos et al., 2020). Currently, a wide range of coating materials are being extensively used namely starch, cellulose, chitosan, guar gum etc., as encapsulating materials which enhance the bioactive potential of EOs (Kumar et al., 2020). Moreover encapsulation of EOs improves the bioactive properties of essential oils and can be used in food and pharmaceutical industries (Kapustova et al., 2021). Nano carriers can be utilised for encapsulating essential oils with enhanced antifungal activity (Kapustova et al., 2021; Napoli et al., 2020). Furthermore, nano based essential oil capsules show controlled mycotoxin and fungal contamination in agri based food systems (Chaudhari et al., 2021). This review illustrates various techniques/methods for encapsulation of essential oils. 


\section{Chemical nature of essential oils}

EOs are complex mixture of compounds which are mostly alcohols, ethers, aldehydes, ketones, esters, amines, phenols and terpenes (Dihifi et al., 2016; Sell, 2006). The terpene family occupies the major composition of EOs. Thousands of compounds belonging to terpenes have been characterized in essential oils namely, alcohol derivatives (geraniol), ketones (menthone), aldehydes (citronellal) and phenols (thymol) (Modzelweska et al.,2005). They are rich in monoterpenes, which include geraniol, terpineol (lilacs), limonene (citrus), myrcene (hops), linalool (lavender) and pinene (pine) and sequiterpenes like chamazulene (German chamomile) (Breitmaier, 2006). Non-terpene compounds such as eugenol, saffrole etc., are also present in EOs. Some esters are also found in EOs such as linalyl acetate and geraniol acetate in lavender and sweet marjoram respectively (Safayhi et al., 1994; Arumugam et al., 2016). Essential oils containing ketones include rosemary, clary and sage (Nazzaro et al., 2013).Some selected essential oils and their major chemical compounds are illustrated in (Table 1).

Various volatile components present in essential oils possess biocidal activity. These volatile compounds have a profound demand in wide spanning industries like food, pharmaceutical and pesticide. Chemical compounds present in EOs and their biocidal activities are depicted in Table 2.

\section{Different techniques of essential oil nanoencapsulation}

Essential oils can undergo chemical alterations because of their volatility and decomposition when exposed to light, heat and oxygen (Scott, 2005). Nanoencapsulation of EOs, involve two terminologies namely core materials and wall materials. The material which gets encapsulated is known as the core material, active agent or internal phase, whereas, the encapsulating substances are called as wall materials, matrices, carrier agent or external phase (Zuidam and Shimoni, 2010; Pandit et al., 2016). Encapsulation of essential oils leads to their sustained release in a controlled manner, can penetrate deep inside the tissues and are readily taken up by the cells because of their miniscule size (Ravi Kumar, 2000). Thus, nanoencapsulation of essential oils leads to their increased bioavailability, enhanced controlled release and precision targeting of the bioactive compounds (Mozafari et al., 2006).

\section{Nanoencapsulation techniques}

Nanoencapsulation of bioactive compounds either involve top-down or bottom-up approaches. In top-down approach, precise tools are applied to reduce the size and shape to achieve desirable applicability of the nanomaterials that are created. On the other hand, the bottom-up approach constructs materials through self-organization and selfassembly of molecules and is influenced by several factors such as temperature, $\mathrm{pH}$, ionic strength and concentration (Augustin and Sanguansri, 2009).

\section{Classical approaches of essential oil nano- -encapsulation}

\section{Emulsification}

This technique has been used to encapsulate bioactive compounds in aqueous solutions by producing nanoemulsions which are colloidal dispersions consisting of two immiscible liquids, one being dispersed into the other having droplet sizes in the range of 50 to $1,000 \mathrm{~nm}$ (Sanguansri and Augustin, 2006). Drying techniques like spray drying and freeze drying after emulsification can be used to produce nanoemulsions that can either be used directly in the liquid state or in a dried powder form. Nanoemulsions exhibit high kinetic stability because of their extremely small emulsion droplet size and this plays a critical role in the retention of surface oil content of the product (Solans et al., 2005; SonnevilleAubrun et al., 2004; Jafari et al., 2008). Being a nonequilibrium system, spontaneous formation of nanoemulsions is not possible and consequently requires energy input. Hence production of nanoemulsions is generally attained

Table 1: Selected essential oils and their chemical composition.

\begin{tabular}{llll}
\hline Plants & Parts used & Chemical components & References \\
\hline Artimisiafrigid & Aerial parts & 1,8-cineole & Lopes-Lutz et al., 2008 \\
Cuminum cyminum & Leaves & $\gamma$-Terpin-7-al, $\gamma$-terpinene, $\beta$-pinene, Cuminaldehyde & Bisht et al., 2014 \\
Eugenia caryophllata & Flower buds & Thymol, eugenol, carvacrol, cinnamaldehyde & Santos et al., 2015 \\
Ocimum basilicum & Leaves, stems & methylchavicol, $\gamma$-terpinene & Arumugam et al., 2016 \\
Nigella sativa & Seeds & longifolene, Thymoquinonethymohydroquinone, & Beatovic et al., 2015 \\
& & $\alpha$-thujene, p-cymene & \\
\hline
\end{tabular}

Table 2: Selected active ingredients and the pathogens inhibited.

\begin{tabular}{lll}
\hline Major active ingredients (MAls) & Pathogens inhibited & Reference \\
\hline Santolina triene, $\alpha$-pinene, camphene & Escherichia coli, Staphylococcus aureus, & Lopes-Lutz et al., 2008 \\
1,8-cineole, methylchavicol, camphor & E. coli, S. Aureus, S. epidermidi & Lopes-Lutz et al., 2008 \\
$\beta$-Himachalene, $\alpha$-humulene, $\gamma$-himachalene & S. aureus, Listeria monocytogenes, & Ait-Ouazzou et al., 2012 \\
& Enterococcus faecium & Bisht et al., 2014 \\
$\gamma$-Terpin-7-al, $\gamma$-terpinene, $\beta$-pinene, Cuminaldehyde & Salmonella typhimurium, E. coli & Santos et al., 2015 \\
\hline
\end{tabular}


through high-energy emulsification methods. Nanoemulsions provide significant possibility for the encapsulation of bioactive food supplements or oil-soluble nutraceuticals that can be utilized in food stuffs (Silva et al., 2012).

\section{Coacervation}

The technique of coacervation involves phase separation of single or mixture of polyelectrolytes from a solution with later deposition of these around essential oil or bioactive components resulting in the formation of coacervates. When cross linking agents like glutaraldehyde and transglutaminase are added to coacervates, the coacervate becomes more robust (Tiwari et al., 2020). Significant increase in the antimicrobial and antioxidant potential of Pimentadioca essential oil after encapsulation in chitosan/carrageenan using the method of complex coacervation had been reported (Dima et al., 2014).

\section{Inclusion complexation}

This technique, in general refers to the encapsulation of a supra-molecular association of a ligand into a cavity-bearing substrate i.e., shell material by Vander Waals force. This technique is chiefly utilized to encapsulate volatile organic molecules like essential oils and vitamins. Essential oils are nanoencapsulated by entrapping them inside a polymer cavity by utilizing hydrogen bond and Vander Waals forces. Cyclodextrins have been widely used polymers to nanoencapsulate essential oils using this technique (Tiwari et al., 2020).

\section{Trending approaches in essential oil nanoencapsulation \\ Electro spinning}

It is a process of producing nanofibers utilizing high electric voltage. Its principle is based on the processing of bio- polymers by exposing to high electric impulses. The resulting materials are nano structures showing better performances over bulk materials (Rostamabadi et al., 2020). Nanofibers prepared by electrospinning have excellent characteristics, such as controllable fiber diameter, high porosity and large specific surface area. Furthermore, various functional active substances can be added to the spinning solution to prepare nanofibers with a wide range of functional properties (Yao et al., 2021). Various variables/parameters governing the production of nano fibres using this technique are:-

- Parameters governing the process (electric field intensity).

- Solution characteristics (viscosity, surface tension).

- Electrospinning environment (temperature) (Jaiturong et al., 2018; Rostamabadi et al., 2020; Ding et al., 2019).

The process of electrospinning can be categorized into coaxial electrospinning, single nozzle electrospinning (Dev and Hemamalini, 2018) and emulsion electrospinning (Garia-Moreno et al., 2016; Feng et al., 2019). Electrospin based nano structures can be efficiently utilised for encapsulating bioactive moleculess (Rostamabadi et al., 2020). In addition to various advantages of electrospinning technique, some limitations also accompany this process. These include:

- Industrial up scaling in an eco-friendly way.

- Inadequate in vivo studies.

- Precise solvent evaporation control rate.

Therefore, further research in this approach is necessary in order to circumvent these limitations.

\section{Electro-spraying}

Electro-spraying is a promising approach as it is versatile and possesses properties like no use of organic solvents and high temperature (Wang et al., 2020; Jawarok et al., 2008; Zhu et al., 2012). It is an emerging area of research

Table 3: Various nano-encapsulation techniques, the steps involved and their uses.

\begin{tabular}{lll}
\hline Nanoencapsulation techniques & Steps involved in technique & Uses \\
\hline Nanoprecipitation & Precipitation of polymer from organic & Best suited for encapsulating \\
& phase (comprised of organic solvent, & hydrophobic substance (EOs)
\end{tabular}

phase (comprised of organic solvent, polymer and bioactives) on addition of aqueous phase (comprised mixture of polymer non solvents along with surfactants).

Inclusion complexation $\quad$ Entrapment of sample inside polymer cavity through Van der Waals forces and hydrogen bonding. Cyclodextrins are the most commonly used polymer for encapsulating EO through inclusion complexation.

Liposome
Formation of membranous structure of liposome colloid particle due to the dispersion of phospholipids in aqueous phase. in comparison to hydrophilic core material.

Formation of transparent Kfoury et al., 2019 solutionand increment in water solubility, protection against degradation upto 44-fold leading to physical and chemical stability.

Suitable carrier for hydrophobic, hydrophilic and amphipathic

Sherry et al., 2013 compounds as well as increased bioavailability, stability and water solubility of encapsulated compound along with enhanced bio-efficacy. 
Table 4: Various nanoencapsulated essential oils/compounds and their antimicrobial activity.

\begin{tabular}{|c|c|c|c|c|}
\hline Essential oil & Method & Microbes & Results & References \\
\hline Zataria multiflora & Ionic gelation & Botrytis cinerea & $\begin{array}{l}\text { Complete inhibition of fungal } \\
\text { growth at } 1500 \mathrm{ppm} .\end{array}$ & $\begin{array}{l}\text { Mohammadi } \\
\text { et al., } 2015 \mathrm{~b}\end{array}$ \\
\hline $\begin{array}{l}\text { Clove } \\
\text { (Syzygiumaro maticu) }\end{array}$ & $\begin{array}{l}\text { Oil in water } \\
\text { emulsion }\end{array}$ & Aspergillus niger & $\begin{array}{l}\text { Better results were observed at } \\
1.5 \mathrm{mg} / \mathrm{mL} \text { as compared to free oil. }\end{array}$ & $\begin{array}{l}\text { Hasheminejad } \\
\text { et al., } 2019\end{array}$ \\
\hline Thymus vulgaris & Nanogel & Aspergillus flaves & $\begin{array}{l}\text { Completely inhibited the growth of } \\
\text { Aspergillus flavus at } 500 \mathrm{mg} / \mathrm{L} \text {. }\end{array}$ & $\begin{array}{l}\text { Khalili et al., } \\
2015\end{array}$ \\
\hline Lime essential oil & Nanoprecipittion & $\begin{array}{l}\text { Staphylococcus aureus, } \\
\text { Listeria monocytogenes, } \\
\text { Shigella dysenteriae and } \\
\text { Escherichia coli }\end{array}$ & $\begin{array}{l}\text { For CSNPS-LEO, the minimum } \\
\text { inhibitory volume (MIV) was } 2.5 \mathrm{~mL} \\
\text { for } E \text {. coli and } 1.25 \mathrm{~mL} \text { for } S \text {. aureus, } \\
\text { L. monocytogenes and } S \text {. dysenteriae. } \\
\text { While for CSNCs-LEO (nanocapsules) } \\
\text { it was } 5 \mathrm{~mL} \text { for } S \text {. aureus, L. } \\
\text { monocytogenes and } S \text {. dysenteriae } \\
\text { and } 10 \mathrm{~mL} \text { for } E \text {. coli. }\end{array}$ & $\begin{array}{l}\text { Sotelo-Boyas } \\
\text { et al., } 2017\end{array}$ \\
\hline $\begin{array}{l}\text { Cardamom } \\
\text { essential oil }\end{array}$ & Ionic gelation & $\begin{array}{l}\text { E. coli and } \\
\text { Staphylococcus aureus }\end{array}$ & $\begin{array}{l}\text { MIC for E. coli was } 25 \%(\mathrm{v} / \mathrm{v}) \text { and for } \\
\text { S. aureus } 10 \%(\mathrm{v} / \mathrm{v}) \text {. }\end{array}$ & $\begin{array}{l}\text { Jamil et al., } \\
2016\end{array}$ \\
\hline $\begin{array}{l}\text { Cinnamomum } \\
\text { zeylanicum }\end{array}$ & Ionic gelation & Phytophthora drechsleri & $\begin{array}{l}\text { Significant reduction in the disease } \\
\text { severity at } 1.5 \mathrm{~g} / \mathrm{L} \text { as revealed through } \\
\text { in vivo studies. }\end{array}$ & $\begin{array}{l}\text { Mohammdi } \\
\text { et al., } 2015\end{array}$ \\
\hline Ocimum sanctum & Nanoemulsion & Aspergillus flavus & $\begin{array}{l}\text { The minimum inhibitory concentration } \\
\text { was } 60 \mu \mathrm{L} / \mathrm{L} \text { plus minimum aflatoxin } \\
\text { inhibitory concentration was } 30 \mu \mathrm{L} / \mathrm{L} \text {. }\end{array}$ & $\begin{array}{l}\text { Singh et al., } \\
2019\end{array}$ \\
\hline Mentha piperita & Nanogel & Aspergillus flavus & $\begin{array}{l}\text { Completely inhibited the growth of } \\
\text { Aspergillus flavus at } 500 \mathrm{ppm} \text {. }\end{array}$ & $\begin{array}{l}\text { Singh et al., } \\
2019\end{array}$ \\
\hline $\begin{array}{l}\text { Savory essential } \\
\text { oil (SEO) }\end{array}$ & $\begin{array}{l}\text { Nanocomposit- } \\
\text { e films }\end{array}$ & $\begin{array}{l}\text { Listeria monocytogenes, } \\
\text { Staphylococcus aureus } \\
\text { Bacillus cereus and } \\
\text { Escherichia coli. }\end{array}$ & $\begin{array}{l}\text { SEO can be used as active packaging } \\
\text { for improving the safety and shelf-life } \\
\text { of food stuff. }\end{array}$ & $\begin{array}{l}\text { Atef et al., } \\
2015\end{array}$ \\
\hline $\begin{array}{l}\text { Peppermint and } \\
\text { green tea oil }\end{array}$ & $\begin{array}{l}\text { Emulsification- } \\
\text { ionic gelation }\end{array}$ & $\begin{array}{l}\text { Escherichia coli and } \\
\text { Staphylococcus aureus }\end{array}$ & $\begin{array}{l}\text { Antibacterial activity of CS/GTO NP } \\
\text { was more potent than CS/PO NP } \\
\text { against Staphylococcus aureus with } \\
9.4 \text { folds improvement compared to } \\
\text { pure GTO and } 4.7 \text { fold against } \\
\text { Escherichia coli. }\end{array}$ & $\begin{array}{l}\text { Shetta et al., } \\
2019\end{array}$ \\
\hline $\begin{array}{l}\text { Gaultheria } \\
\text { procumbens }\end{array}$ & Nanogel & Aspergillus flavus & $\begin{array}{l}\text { Completly inhibited thegrowth of } \\
\text { A. flavus and aflatoxin B1 production } \\
\text { at } 1.0 \mathrm{~mL} / \mathrm{mL}\end{array}$ & $\begin{array}{l}\text { Kujur et al., } \\
2017\end{array}$ \\
\hline Cymbopogn martinii & $\begin{array}{l}\text { Emulsification } \\
\text { technique }\end{array}$ & F. graminearum & $\begin{array}{l}\text { Ce-CMEO-NPs were presented } \\
\text { efficient with enhanced antifungal } \\
\text { and antimycotoxin activities and it } \\
\text { could be due to perseverance of } \\
\text { antifungal activity by controlled } \\
\text { release of antifungal constituents } \\
\text { from Ce-CMEO-NPs. }\end{array}$ & $\begin{array}{l}\text { Kalagatur } \\
\text { et al., } 2018\end{array}$ \\
\hline Myristica fragrans & Nanogel & Aspergillus flavus & $\begin{array}{l}\text { Minimum inhibitory concentration } \\
\text { (MIC) and minimum aflatoxin } \\
\text { inhibitory concentration was } 1.25 \mu \mathrm{L} / \mathrm{L} \text {. }\end{array}$ & $\begin{array}{l}\text { Yadav et al., } \\
2019\end{array}$ \\
\hline Satureja hortensis & Ionic gelation & $\begin{array}{l}\text { Staphylococcus aureus, } \\
\text { Listeria monocytogenes }\end{array}$ & $\begin{array}{l}\text { All EO loaded NP samples completely } \\
\text { inhibited the growth of bacteria. }\end{array}$ & $\begin{array}{l}\text { Feyzioglu } \\
\text { et al., } 2016\end{array}$ \\
\hline
\end{tabular}


Table 4: Continue....

\begin{tabular}{|c|c|c|c|c|}
\hline Pelargoning L. & Nanogel & Aspergillus flavus & $\begin{array}{l}\text { Inhibition of the growth as well as aflatoxin } \\
B_{1} \text { synthesis at } 1.00 \mu \mathrm{LL}^{-1} \text {, as compared } \\
\text { to the free oil at } 1.25 \mu \mathrm{LmL}^{-1} \text {. }\end{array}$ & $\begin{array}{l}\text { Kujur et al., } \\
2020\end{array}$ \\
\hline $\begin{array}{l}\text { Origanum vulgare, } \\
\text { Eucalytus globulus }\end{array}$ & Nanoemulsion & $\begin{array}{l}\text { Aeromonas hydrophila, } \\
\text { Streptococcus iniae }\end{array}$ & $\begin{array}{l}\text { The best antibacterial potential was shown } \\
\text { by the nanoemulsion of Origanum vulgare } \\
\text { (oregano) having } 3.12 \mu \mathrm{g} / \mathrm{ml} \text { as minimal } \\
\text { inhibitory concentration (MIC) and minimum } \\
\text { bactericidal concentration (MBC) against all } \\
\text { strains. }\end{array}$ & $\begin{array}{l}\text { Gholipouranar } \\
\text { et al., } 2019\end{array}$ \\
\hline Monarda citriodora & Nanoparticle & $\begin{array}{l}\text { Aspergillus flavus and } \\
\text { other storage moulds }\end{array}$ & $\begin{array}{l}\text { Broad spectrum fungitoxicity and completely } \\
\text { inhibited the growth of all tested molds and } \\
\text { aflatoxin B1 (AFB1) synthesis by AF-LHP- } \\
\text { SH1 at } 1.40 \text { and } 1.20 \mu \mathrm{L} / \mathrm{ml} \text { respectively. }\end{array}$ & $\begin{array}{l}\text { Deepika } \\
\text { et al., } 2020\end{array}$ \\
\hline
\end{tabular}

for encapsulating bio active compounds. Here polymer liquids are exposed to high electric field resulting in fine liquid droplets. Nano sized particles are the final processed products when the solvents (in liquid particles) are evaporated. Various challenges such as low throughput hinder its large scale commercialization. Moreover electrosprayed products are subjected to aggregation and need appropriate wall materials (Wang et al., 2020).

\section{Supercritical fluid technique}

Conventional encapsulation techniques employ the use of high temperatures/evaporation which limits or deteriorates the structures of volatile oils. Techniques such as supercritical fluid encapsulation can be used as an alternative. It involves non-pre/post thermal processing (Akolade et al., 2020). It is broadly utilized due to its low critical temperature requirement as well as minimal utilization of organic solvents (Ezhilarasi et al., 2013). The SCF technique can be categorized according to the function of SCF in the encapsulation process, as solvent, antisolvent, solute or cosolvent, nebulization compound, extractor and antisolvent techniques (Keven et al. 2014). There are various techniques that involve supercritical fluids and these include supercritical anti-solvent process (SAS) and its various modifications, rapid expansion of supercritical solutions (RESS), gas antisolvent process (GAS), supercritical fuid extraction of emulsions (SFEE), aerosol solvent extraction system (ASES), precipitation with compressed fluid antisolvent (PCA) etc. However, the SAS has recently received an enormous attention more than other methods because of its feasibility of application (Nerome et al. 2013; Esfandiari and Ghoreishi 2015).

\section{Nanoprecipitation/solvent displacement}

Its principle relies on the precipitation of polymer from organic phase on addition of an aqueous phase (Singh et al, 2020). It is an effective method to produce nanocapsules in the size range of $100 \mathrm{~nm}$ and below which exhibit properties like, good stability against degradation, sustained release, higher encapsulation efficiency and enhanced bioavailability during in vivo studies along with displaying enhanced uptake by cells (Ezhilarasi et al., 2013). Appropriate solvent and non solvent phase need to be selected, which may vary for each bioactive components and the polymer and solvent need to be of food grade. Since it is a fast and economic method, it has been found to be most suitable for encapsulating hydrophobic substance than hydrophilic core materials (Ladj-Minost, 2012). Table 3 summarizes the techniques used for the encapsulation of essential oils.

\section{Augmented antimicrobial activities of essential oil}

Essential oils are sensitive volatile liquids which can be readily degraded when exposed to environmental factors (Sebesan and Caraban, 2008). Therefore to protect them from these intrinsic factors, essential oil formulations came in light which involves dispersing them in special carrier materials such as nanogels and nanoemulsions which has high loading capacity, high stability and significant release properties (Rasoli et al., 2008). Thus, encapsulation is one of the most efficient methods for the formulation of bioactive oils and various approaches have been developed in this direction. EOs exhibit potential antimicrobial activities against a wide spectrum of micro flora. The interest in the use of essential oils as natural antimicrobials and preservatives in the food industry has geared up in the last years due to growing consumer demand for natural and safe preservatives with good organoleptic properties. Various encapsulated oils and their antimicrobial activity with improved efficacy has been shown in (Table 4).

\section{CONCLUSION}

In conclusion, many essential oils exhibit antimicrobial activity against foodborne pathogens due to the synergism of their major and minor components. The precise molecular composition of essential oils plays an important role in determining their antimicrobial efficacy. Due to their low water solubility, strong organo-leptic properties and low stability together with the high volatility they find a little application in medicine. Most of these drawbacks can be overcome by nano-encapsulating EOs thereby, lowering their dose and increasing long-term stability. Nano-encapsulation of EOs in liposomes, solid lipid nanoparticles, nano and micro-emulsions 
and polymeric nanoparticles represent a promising strategy for overcoming their limitations. Although a number of different types of delivery systems have been developed, there is still a relatively poor understanding of the major factors governing the rational design of these systems for particular applications.

\section{REFERENCES}

Ait-Ouazzou, A., Loran, S., Arakrak, A., Laglaoui, A., Rota, C., Herrera, A., Pagán, R., Conchello, P. (2012). Evaluation of the chemical composition and antimicrobial activity of Menthapulegium, Juniperusphoenicea and Cyperus longus essential oils from Morocco. Food Research International. 45: 313-319.

Akolade, J.O., Nasir-Naeem, K.O., Swanepoel, A., Yusuf, A.A., Balogun, M., Labuschagne, P. (2020). CO ${ }^{2}$-assisted production of polyethylene glycol / lauric acid microparticles for extended release of Citrus aurantifolia essential oil. Journal of $\mathrm{CO}^{2}$ Utilization. 38: 375-384.

Arumugam, G., Swamy, M., Sinniah, U. (2016). Plectranthus amboinicus (Lour.) Spreng: Botanical, phytochemical, pharmacological and nutritional significance. Molecules. 21: 369.

Atef, M., Rezaei, M., Behrooz, R. (2015). Characterization of physical, mechanical and antibacterial properties of agar - cellulose bio-nano-composite films incorporated with savory essential oil. Food Hydrocolloids. 45: 150-157.

Augustin, M.A. and Sanguansri, P. (2009). Nanostructured materials in the food industry. Advances in Food and Nutrition Research. 58(4): 183-213.

Bastos, L.P.H., Vicente, J., dos Santos, C.H.C., de Carvalho, M.G. and Garcia-Rojas, E.E. (2020). Encapsulation of black pepper (Piper nigrum L.) essential oil with gelatin and sodium alginate by complex coacervation. Food Hydrocolloids. 102: 105605.

Beatovic, D., Krstic-Milosevic, D., Trifunovic, S., Siljegovic, J., Glamoclija, J., Ristic, M., Jelacic, S. (2015). Chemical composition, antioxidant and antimicrobial activities of the essential oils of twelve Ocimum basilicum L. cultivars grown in Serbia. Records of Natural Products. 9: 62-75.

Bisht, D.S., Menon, K., Singhal, M.K. (2014). Comparative antimicrobial activity of essential oils of Cuminum cyminum L. and Foeniculum vulgare Mill. seeds against salmonella typhimurium and Escherichia coli. Journal of Essential Oil-Bearing Plants. 17: 617-622.

Breitmaier, E. (2006). Terpenes: Flavors, fragrances, pharmaca, pheromones. John Wiley and Sons. Builders, P.F., Arhewoh, M.I. (2016). Pharmaceutical applications of native starch in conventional drug delivery. Starch Staerke. 68: 864-873.

Chaudhari, A.K., Singh, V.K., Das, S. and Dubey, N.K. (2021). Nanoencapsulation of essential oils and their bioactive constituents: A novel strategy to control mycotoxin contamination in food system. Food and Chemical Toxicology. 149: 112019.

Deepika, Singh, A., Chaudhari, K.A., Das, S., Dubey, K.N. (2020). Nanoencapsulated Monardacitriodora Cerv.ex Lag. essential oil as potential antifungal and antiaflatoxigenic agent against deterioration of stored functional food. Journal of Food Science and Technology. 57: 2863-2876.
Dev, V.G., Hemamalini, T. (2018). Porous electrospun starch rich polycaprolactoneblend nanofibers for severe hemorrhage. International Journal of Biological Macromolecules. 118: 1276-1283.

Dihifi, W., Bellili, S., Jazi, S., Bahloul, N., Mnifi, W. (2016). Essential oils Chemical characterization and investigation of some biological activities-A critical review. Medicines. 3(4): 25.

Dima, C., Cotarlet, M., Alexe, P., Dima, S. (2014). Microencapsulation of essential oil of pimento [Pimenta dioica (L.) Merr.] by chitosan/k-carrageenan complex coacervation method. Innovative Food Science and Emerging Technology. 22: 203-211.

Ding, Y., Li, W., Zhang, F., Liu, Z., Ezazi, N.Z., Liu, D., Santos, H.A. (2019). Electrospun fibrous architectures for drug delivery, tissue engineering and cancer therapy. Advanced Functional Materials. 29(2): 1-35.

Dorman, H.J.D., Deans, S.G. (2000). Antimicrobial agents from plants: Antibacterial activity of plant volatile oils. Journal of Applied Microbiology. 88: 308-316.

Esfandiari, N., Ghoreishi, M. (2015). Ampicillin nanoparticles production via supercritical $\mathrm{CO}^{2}$ gas antisolvent process. American Association of Pharmaceutical Scientists Pharma Science and Technology. 16: 1263-1269.

Ezhilarasi, P.N., Karthik, P., Chhanwal, N., Anandharamakrishnan, C. (2013). Nanoencapsulation techniques for food bioactive components, A review. Food and Bioprocess Technology. 6(3): 628-647.

Feng, X., Li, J., Zhang, X., Liu, T., Ding, J., Chen, X. (2019). Electrospun polymer micro/nanofibers as pharmaceutical repositories for healthcare. Journal of Controlled Release. 302: 19-41.

Feyzioglu, G.C., Tornuk, F. (2016). Development of chitosan nanoparticles loaded with summer savory (Satureja hortensis L.) essential oil for antimicrobial and antioxidant delivery applications. LWT-Food Science and Technology. 70: 104-110.

Garcia-Moreno, P.J., Stephansen, K., Vander, K.J., Guadix, A., Guadix, E.M., Chronakis, I.S., Jacobsen, C. (2016). Encapsulation of fish oil in nanofibers by emulsion electrospinning: Physical characterization and oxidative stability. Journal of Food Engineering. 183: 39-49.

Gholipourkanani, H., Lymbery, A., Buller, N. (2019). In vitro antibacterial activity of four nano encapsulated herbal essential oils against three bacterial fish pathogens. Aquatic. Research. 50(3): 871-875

Hasheminejad, N., Khodaiyan, F., Safari, M. (2019). Improving the antifungal activity of clove essential oil encapsulated by chitosan nanoparticles, Food Chemistry. 275: 113-122.

Herman, R.A., Ayepa, E., Shittu, S., Fometu, S.S., Wang, J. (2019). Essential oils and their Applications-A mini review. Advances in Nutrition and Food Science. 4(4): 1-13.

Jafari, S.M., Assadpoor, E., Bhandari, B., He, Y. (2008). Nanoparticle encapsulation of fish oil by spray drying. Food Research International. 41(2): 172-183.

Jaiturong, P., Sirithunyalug, B., Eitsayeam, S., Asawahame, C., Tipduangta, P., Sirithunyalug, J. (2018). Preparation of glutinous rice starch/polyvinyl alcohol copolymer electrospun fibers for using as a drug delivery carrier. Asian Journal of Pharmaceutical Sciences. 13(3): 239-247. 
Jamil, B., Abbasi, R., Abbasi, S., Imran, M., Khan, S.U., Ihsan, A., Javed, S., Bokhari, H. (2016). Encapsulation of cardamom essential oil in chitosan nano-composites: In vitro efficacy on antibiotic-resistant bacterial pathogens and cytotoxicity studies. Frontiers in Microbiology. 7: 1580.

Jaworek, A., Sobczyk, A.T. (2008). Electrospraying route to nanotechnology: An overview. Journal of Electrostatics. 66: 197-219.

Kalagatur, N.K., Ghosh, O.S.N., Sundararaj, N. and Mudili, V. (2018). Antifungal activity of chitosan nanoparticles encapsulated with Cymbopogon martinii essential oil on plant pathogenic fungi Fusarium graminearum. Frontiersin Pharmacology. 9.

Kapustova, M., Granata, G., Napoli, E., Puskarova, A., Buckova, M., Pangallo, D. and Geraci, C. (2021). Nanoencapsulated essential oils with enhanced antifungal activity for potential application on agri-food, material and environmental fields. Antibiotics. 10: 31.

Keven, E.S., Angela, M., Meireles, A. (2014). Encapsulation of food compounds using supercritical technologies: Applications of supercritical carbon dioxide as an antisolvent. Food and Public Health. 4(5): 247-258.

Kfoury, M., Auezova, L., Greige-Gerges, H. and Fourmentin, S. (2019). Encapsulation in cyclodextrins to widen the applications of essential oils. Environmental Chemistry Letters. 17(1): 129-143.

Khalili, S.T., Mohsenifar, A., Beyki, M., Zhaveh, S., Rahmani-Cherati, T., Abdollahi, A., Bayat, M. and Tabatabaei, M. (2015). Encapsulation of thyme essential oils in chitosan-benzoic acid nanogel with enhanced antimicrobial activity against Aspergillus flavus. Food Science and Technology. 60: 502-508.

Kujur, A., Kiran, S., Dubey, N.K. and Prakash, B. (2017). Microencapsulation of Gaultheria procumbens essential oil using chitosancinnamic acid microgel: Improvement of antimicrobial activity, stability and mode of action. LWT - Food Science and Technology. 86: 132-138.

Kujur, A., Kumar, A., Yadav, A. and Prakash, B. (2020). Antifungal and aflatoxin B1 inhibitory efficacy of nanoencapsulated Pelargonium graveolens $\mathrm{L}$. essential oil and its mode of action. LWT- Food Science and Technology. 130: 109619.

Kumar, A., Singh, P. and Gupta, V. (2020). In: Applications of nanotechnology to boost the functional and preservatives properties of essential oils. Functional and Preservative properties of phytochemicals, Elseiver Inc. (pp.241-267)

Ladj-Minost, A. (2012). In: Long-acting arthropod repellents: Pharmacotechnical study, becoming in situ and efficacy (Doctoral dissertation).

Lambert, R.J.W., Skandamis, P.N., Coote, P. and Nychas, G.J.E. (2001). A study of the minimum inhibitory concentration and mode of action of oregano essential oil, thymol and carvacrol. Journal of Applied Microbiology. 91: 453-462.

Lopes-Lutz, D., Alviano, D.S., Alviano, C.S. and Kolodziejczyk, P.P. (2008). Screening of chemical composition, antimicrobial and antioxidant activities of Artemisia essential oils. Phytochemistry. 69: 1732-1738.

Mahato, N., Sharma, K., Koteswararao, R., Sinha, M., Baral, E. and Cho, H.M. (2019). Citrus essential oils: Extraction, authentication and application in food preservation. Critical Reviews in Food Science and Nutrition. 59: 611-625.
Modzeleweska, A., Sur, S., Kumar, K.S. and Khan, S.R. (2005). Sesquiterpenes: Natural products that decrease cancer growth. Current Medicinal Chemistry-Anti-Cancer Agents. 5(5): 477-499.

Mohammadi, A., Hashemi, M. and Hosseini, S.M. (2015). Chitosan nanoparticles loaded with Cinnamomum zeylanicum essential oil enhance the shelf life of cucumber during cold storage. Postharvest Biology and Technology. 110: 203-213.

Mohammadi, A., Hashemi, M. and Hosseini, S.M. (2015b). Nanoencapsulation of Zataria multiflora essential oil preparation and characterization with enhanced antifungal activity for controlling Botrytis cinerea, the causal agent of gray mould disease. Innovative Food Science and Emerging Technologies. 28: 73-80.

Mozafari, M.R. (2006). Bioactive Entrapment and Targeting using Nanocarrier Technologies: An Introduction. In: Nanocarrier Technologies: [Mozafari, M.R. (Ed.)], Frontiers of Nanotherapy. Springer, Netherlands, pp. 1.

Napoli, E., Siracusa, L., Ruberto, G. (2020). New tricks for old guys: Recent developments in the chemistry, biochemistry, applicationsand exploitation of selected species from the Lamiaceae family. Chem. Biodiver. 17: 1900677.

Nazzaro, F., Fratianni, F., Martino, L.D., Coppola, R. and Feo, V.D. (2013). Effect of essential oils on pathogenic bacteria. Pharmaceuticals. 6: 1451-1474.

Nerome, H., Machmudah, S., Wahyudiano, F.R., Higashiura, T., Youn, Y-S., Lee, Y-W., Gato, M. (2013). Nanoparticle formation of lycopene/ $\beta$-cyclodextrin inclusion complex using supercritical anti- solvent precipitation. Journal of Supercritical Fluids. 83: 97-103.

Pandit, J., Aqil, M. and Sultana, Y. (2016). Nanoencapsulation technology to control release and enhance bioactivity of essential oils. In Encapsulations. Academic Press. (pp. 597-640).

Pichersky, E., Noel, J.P. and Dudareva, N. (2006). Biosynthesis of plant volatiles: Nature's diversity and ingenuity. Science. 311: 808-811.

Pophof, B., Stange, G. and Abrell, L. (2005). Volatile organic compounds as signals in a plant-herbivore system: Electrophysiological responses in olfactory sensilla of the moth Cactoblastis cactorum. Chemical Senses. 30: 51-68.

Rasoli, I., Fakoor, M.H., Yadegarinia, D., Gachkar, L., Allameh, A. and Rezaei, M.B. (2008). Antimycotoxigenic characteristics of Rosmarinus officinalis and Trachyspermum copticum L. essential oils. International Journal of Food Microbiology. 122: $135-139$.

Ravi Kumar, N.M. (2000). Nano and microparticles as controlled drug delivery devices. Journal of Pharm and Pharmaceutical Sciences. 3: 234-258.

Rosset, V., Ahmed, N., Zaanoun, I., Stella, B., Fessi, H. and Elaissari, A. (2012). Elaboration of argan oil nanocapsules containing naproxen for cosmetic and transdermal local application. Journal of Colloid Science and Biotechnology. 1(2): 218224.

Rostamabadi, H., Assadpour, E., Tabarestani, H.S., Falsafi, S.R., Jafari, S.M. (2020). Electrospinning approach for nanoencapsulation of bioactive compounds; Recent advances and innovations, Trends in Food Science and Technology. 100: 190-209. 
Safayhi, H., Sabieraj, J., Sailer, E.R. and Ammon, H.P. (1994). Chamazulene: An antioxidant-type inhibitor of leukotriene B4 formation. Planta Medica. 60: 410-413.

Sanguansri, P. and Augustin, M.A. (2006). Nanoscale materials development- A food industry perspective. Trends in Food Science and Technology. 17(10): 547-556.

Santos, N.O., Mariane, B., Lago, J.H., Sartorelli, P., Rosa, W., Soares, G.M., Silva, D.M.A., Lorenzii, H., Vallim, A.M. and Pascon, C.R. (2015). Assessing the chemical composition and antimicrobial activity of essential oils from Brazilian plants- Eremanthu serythropappus (Aster-aceae), Plectrantuns barbatus and $P$. amboinicus (Lamiaceae). Molecules. 20: 8440-8452.

Scott, P.W.R. (2005). In: Encyclopedia of Analytical Science. Essential Oils. [Worsfold, P., Townshend, A., Poole, C. (Eds.)], Second ed. Elsevier, London, UK, pp. 554-561.

Sebesan, M. and Caraban, A. (2008). Analysis of the essential oils from thyme (Thymus vulgaris $\mathrm{L}$ ) and from peppermint (Mentha piperita L). Chemical Bulletin. 53: 1-2.

Sell, C.S. (2006). In: The Chemistry of Fragrance. From Perfumer to Consumer, $2^{\text {nd }}$ ed.; The Royal Society of Chemistry: Cambridge, UK, p. 329.

Sherry, M., Charcosset, C., Fessi, H. and Greige-Gerges, H. (2013). Essential oils encapsulated in liposomes: A review. Journal of Liposome Research. 23(4): 268-275.

Shetta, A., Kegere, J. and Mamdouh, W. (2019). Comparative study of encapsulated peppermint and green tea essential oils in chitosan nanoparticles: Encapsulation, thermal stability, in vitro release, antioxidant and antibacterial activities. International Journal of Biological Macromolecules. 126: 731-742.

Sikkema, J., de Bont, J.A.M. and Poolman, B. (1994). Interactions of cyclic hydrocarbons with biological membranes. Journal of Biological Chemistry. 269: 8022-8028.

Silva, H.D., Cerqueira, M.A., Vicente, A.A. (2012). Nanoemulsions for food applications: development and characterization. Food Bioprocess Technology. 5: 854-867.

Singh, V.K., Das, S., Dwivedy, A.K., Rathore, R. and Dubey, N.K. (2019). Assessment of chemically characterized nanoencapuslated Ocimum sanctum essential oil against aflatoxigenic fungi contaminating herbal raw materials and its novel mode of action as methyglyoxal inhibitor. Postharvest Biology and Technology. 153: 87-95.

Singh, A., Chaudhari, K.A., Das, S., Dubey, K.N. (2020). Nanoencapsulated Monarda citriodora Cerv.ex Lag. essential oil as potential antifungal and antiaflatoxigenic agent against sedeterioration of stored functional food. Journal of Food. Science and Technology. 57: 2863-2876.
Solans, C., Izquierdo, P., Nolla, J., Azemar, N. and Garcia-Celma, M.J. (2005). Nano-emulsions. Current Opinion in Colloid and Interface Science. 10: 102-110.

Sonneville-Aubrun, O., Simmonet, J.T. and Alloret, F.L. (2004). Nanoemulsions: A new vehicle for skin care products. Advances in Colloid and Interface Science. 145-149.

Sotelo-Boyas, M.E., Correa-Pacheco, Z.N., Bautista-Ba-nos, S. and Corona-Rangel, M.L. (2017). Physicochemical characterization of chitosan nanoparticles and nanocapsules incorporated with lime essential oil and their antibacterial activity against food-borne pathogens. Food Science and Technology. 77: $15-20$.

Tiwari, S., Singh, B.K., Dubey, N.K. (2020). Encapsulation of essential oils-A booster to enhance their bio-efficacy as botanical preservatives. Journal of Scientific Research. 64: 175-178.

Tongnuanchan, P. and Benjakul, S. (2014). Essential oils: Extraction, bioactivities and their uses for food preservation. Journal of Food Science. 79: 1231-1249.

Vainstein, A., Lewinsohn, E., Pichersky, E. and Weiss, D. (2001). Floral Fragrance. New Inroads into an Old Commodity. Plant Physiology. 27: 1383-1389.

Wang, P., Ding, M., Zhang, T., Wu, T., Qiao, R., Zhang, F., Wang, X., Zhong, J. (2020). Electrospraying Technique and Its Recent Application Advances for Biological Macromolecule Encapsulation of Food Bioactive Substances, Food Reviews International. 1-24.

Yadav, A., Kujur, A., Kumar, A., Singh, P. P., Prakash, B. and Dubey, N.K. (2019). Assessing the preservative efficacy of nanoencapsulated mace essential oil against food borne molds, aflatoxin B1contamination and free radical generation. LWT - Food Science and Technology. 108: 429-436.

Yao, F., Gao, Y.H., Chen, F.S., Xia, Y.M. (2021). Effects of electrospinning parameters on peanut protein isolate nanofibers diameter. Journal of Food. 19: 729-738.

Zhu, Y., Chen, Y., Xu, G., Ye, X., He, D., Zhong, J. (2012). Micropattern of Nano-hydroxyapatite/silk Fibroin Composite onto $\mathrm{Ti}$ Alloy Surface via Template-assisted Electrostatic Spray Deposition. Materials Science and Engineering C. 32: 390-394.

Zuidam, N.J., Shimoni, E. (2010). Overview of Microencapsulation use in Food Products or Processes and Methods to Make Them. In: Encapsulation Technique for Active Food Ingredients and Food Processing. [N.J. Zuidamand, V.A., Nedovic (Eds.)], New York: Springer. (pp. 3-29). 